\title{
An Analysis of_C-E Translation of Public Signs
}

\author{
Tang Yan \\ College of Foreign Languages and Literature, Wuhan Donghu University, Wu Han, 430212, China
}

Keywords: C-E translation of public signs; common errors; translation guidelines

\begin{abstract}
This paper makes an analysis of common errors in C-E Translation of public signs. In the research of C-E translation of public signs, it is necessary to take account of cultural factors and function of language to produce a functionally adequate target text. Some guidelines to C-E translation of public signs are put forward, including centering on the receptors and using simple language. Meantime, guidelines to public signs with Chinese Characteristics have been studied in this paper.
\end{abstract}

\section{Introduction}

There is increasing recognition of the importance and usefulness of doing research in C-E translation of public signs. In the academic world, there still exist many problems in the studies of C-E translation of public signs that need to be solved. It is significant that every scholar, translator and the official agencies pay their attention to this research field. Although so many scholars are making efforts in this research field, they do not give an all-round introduction of public signs in Chinese. Based on theoretical and practical needs, it is urgent to make a further study and research on the C-E translation of public signs systematically.

\section{Functional Features of Public Signs}

It is significant to make a careful study of the main functional features of the language of public signs when we do research in C-E translation of public signs. Different kind of public signs bear different functions due to different situations and occasions. It is necessary to classify them according to their common functional features although they cover a large variety of aspects in people's social life. Directing, prompting, restricting and compelling are the most important functional features of public signs.

\section{Common Errors in C-E Translation of Public Signs}

The present situation of the language environment inspires us to make more effort to push it forward. Though many scholars work at this research field, the present situation is far from satisfactory. It is not sufficient to simply focus on one aspect and analyze few examples. In addition, many scholars are mainly engaged in linguistic analysis or pragmatic translations when they study errors in C-E translation of public signs. And cultural influences and causes of errors, which are the important elements in this research field, have been neglected. Errors in C-E translation of public signs are still prevalent and the quality of translation leaves much to be desired. If the purpose of a translation is to achieve a particular function for the target addressee, anything that obstructs the achievement of this purpose is a translation error. (Nord, 2001:74).

\section{Guidelines to C-E Translation of Public Signs}

Translation is a complex action designed to achieve a particular purpose. The purpose of translational action is to transfer messages across culture and language barriers by means of message transmitters produced by experts. (Nord, 2001:13). Different contexts call for different translation solutions. A very useful rule in the translation process is that the translation action 
should be guided by the function the translator wants to achieve by means of the translation.

According to M.A.K. Halliday, register theory is a variety of language distinguished according to use and the functional organization of language play an important role in systematic relationship. (Halliday, 1985:11). As tenor is the category used to describe what language is being used for a particular situation and the addresser-addressee relationship is pushed to the most important place when it comes to what the translator should do with language. Centering on the receptors is the most important guideline to achieve the function of C-E translation of public signs. Centering on the receptors indicates that the translator should pay more attention to the receptors' response, and the usage of language should be carefully considered, that is to say, the C-E translation of public signs should be concise, polite and understandable.

C-E translation of public signs must be understandable and acceptable. It aims at achieving the basic function of signs, namely, directing, prompting, restricting and compelling. Judging the validity of a translation cannot stop with a comparison of corresponding word meaning, grammar and rhetorical devices, but should place specific emphasis on the function of the public signs. The noticeable characteristic of public signs is that the words and phrases are very concise and precise, as long as the C-E translation of public signs can come within reach of their specific functions effectively, function words, the core vocabulary and substantive could be used plentifully, and the articles, pronouns and auxiliaries are often omitted.

The language styles of public signs are concise, conventional, conspicuous and convenient. The ideal C-E translation of public signs should be at once close to the original in meaning and appropriate in style to achieve the function of public signs. According to Halliday, there are great differences in the usage of language due to different transmission intentions of the users of language. Translators could work more effectively if they take note of the language style and the functional features of public signs and achieve the purpose of translating by using simple and concise words. For instance, traffic public signs provide foreigners instructive information such as the road information or the information of guiding service to indicate people to do or not to do something. The C-E translation of such kind of public signs must be concise and convenient to achieve the function of directing, such as STOP NO ENTRANCE, STOP PAY TOLL, and NO LEFT TURN. The functions of directing are easy to be approached by using concise and conspicuous words.

Public signs with Chinese characteristics are difficult tasks for the translators, as these signs bear particular characteristics and features. So the translators may adopt certain translation guidelines to deal with them, the most important guideline is that the C-E translation of public signs with Chinese characteristics should aims at their original function, that is, the translation versions aims for preserving the Chinese features and spreading the Chinese culture, meantime, the addresses could be able to get the original meanings of these public signs and also get some local culture from these signs. The aim of conveying cultural information for the addressors makes it necessary to solve poor readability problems. In practical translation, the translator should endeavor to follow the above-mentioned guideline to fulfill their functions.

Though public signs with Chinese characteristics may contain a few words, their translation is by no means easy and the quality of this type signs must be given extraordinary attention. These problems will inevitably influence the image of China and cannot be neglected; the translators and the whole society should make great effort to overcome all the potential problems in sign translation.

\section{Conclusion}

As to new translation guidelines of C-E translation of public signs, not only did it account for different strategies in different translation situations, but it also coincided with a change of paradigm in disciplines, such as linguistic focus, social and cultural-bound occurrence and the on communicative intentions and functions. 


\section{References}

[1] Christiane Nord. (2001) Translating as a purposeful activity: Functionalist approaches explained. Shanghai: Shanghai: Foreign Language Education Press.

[2] Halliday, M.A.K. (1985). Spoken and written language. Oxford: Oxford University Press.

(Tang Yan Wuhan Donghu University)

Associate professor of College of Foreign Languages and Literature, Wuhan Donghu University; Master of Arts; Research Direction: Translation Theory and Practice and Studies of English Teaching and Communication. 